\title{
Comparison between the thermal insulation properties of Huacayo alpaca and Merino sheep fleeces
}

\author{
Maria Soroko $^{1 *}$, Anna Wyrostek ${ }^{2}$, Kevin Howell ${ }^{3}$, and Krzysztof Dudek ${ }^{4}$ \\ ${ }^{I}$ Department of Horse Breeding and Equestrian Studies, Institute of Animal Breeding, Wroclaw University of \\ Environmental and Life Sciences, Wroclaw, Poland \\ ${ }^{2}$ Department of Sheep and Fur Animal Breeding, Institute of Animal Breeding, Wroclaw University of \\ Environmental and Life Sciences, Wroclaw, Poland \\ ${ }^{3}$ Microvascular Diagnostics, Institute of Immunity and Transplantation, Royal Free Hospital, Pond Street, \\ London, United Kingdom \\ ${ }^{4}$ Faculty of Mechanical Engineering, Wroclaw University of Technology, Wroclaw, Poland
}

SOROKO, M., A. WYROSTEK, K. HOWELL, K. DUDEK: Comparison between the thermal insulation properties of Huacayo alpaca and Merino sheep fleeces. Vet. arhiv 89, 519-528, 2019.

\section{ABSTRACT}

The aim of the study was to evaluate and compare the fleece thermal insulation of Huacaya alpacas and Merino sheep. The study included 13 clinically healthy Huacaya alpacas and 14 Merino sheep. Fleece samples were taken from the trunk (lateral aspects) of each animal to measure coat fibre length and average fibre diameter. The insulating properties of each sample were determined using a calorimetric method. In addition, infrared thermographic images were taken of the trunk (lateral aspects) for both species in an indoor environment. Four regions of interest (ROIs) were determined from each thermographic image (corresponding to the coat sample sites) and the mean temperature within each ROI was calculated. Merino sheep had significantly $(\mathrm{P}<0.001)$ longer and thicker fibres than alpacas, but less efficient (by about 20\%) insulation at all sample sites. Sheep in similar experimental conditions therefore had significantly higher fleece surface temperature (by $1-2^{\circ} \mathrm{C}$ ) than Huacaya alpacas. Infrared thermography also provides information about fleece surface temperatures in vivo, which can be used to validate models of heat exchange in homeotherms.

Key words: Alpacas; fibre diameter; fibre length; fleece; sheep; thermal insulation; infrared thermography

\section{Introduction}

Coat insulation plays a major role in body temperature conservation and regulation. Most of the temperature difference between an animal and the air surrounding it is found

\footnotetext{
*Corresponding author:

Maria Soroko, Department of Horse Breeding and Equestrian Studies, Institute of Animal Breeding, Wroclaw University of Environmental and Life Sciences, Kozuchowska 5A, 51-161 Wroclaw, Poland, Phone: +48 507495 109; Fax: +48 713205785 ; E-mail: kontakt@eqma.pl
} 
within the coat, which is the layer between the underlying surface of the skin and the atmosphere. Therefore, the coat temperature is influenced by various energy fluxes which contribute to the animal's energy balance, and it depends on the coat structure and the external microclimate (CENA, 1974; McARTHUR and MONTHEIT, 1980; McCAFFERTY, 2007; SOROKO et al., 2015; SOROKO et al., 2017).

Wool is one of the best textile materials due to its characteristics, including good hygroscopic properties and heat insulation, high tensile strength and ease of spinning. The most popular breed of sheep utilised for wool is the Merino. The fibres are devoid of a medulla (REIS and SAHLU, 1994; SHARMA and PANT, 2013) with a diameter from about 12 to 25 microns (REIS and SAHLU, 1994; SHARMA and PANT 2013; SCOBIE et al., 2015).

Alpacas are also becoming popular in fibre production. There are two main breeds of alpacas: Suri and Huacaya. Suri fibres are finer and longer compared to Huacaya fibres, which are more similar to Merino and Corriedale sheep wool. However, unlike sheep wool, only the minority of alpaca fibres are medulla-free. The medulla present in their structure may be continuous or fragmented (GERKEN, 1997; ANTONINI, 2010; CZAPLICKI, 2012). Numerous studies on sheep and alpaca fibres have indicated their efficient insulating and thermo-active properties (SHAKYAWAR et al., 2007; GERKEN, 2010; MOORE et al., 2011). However, no studies have evaluated and compared the fleece thermal insulation of alpacas and sheep using equivalent techniques. Therefore, the aim of our study was to evaluate and compare fleece thermal insulation of Huacaya alpacas and Merino sheep.

\section{Materials and methods}

Animals. The study was conducted in October 2015 and included clinically healthy Huacaya alpacas $(n=13)$ and Polish Merino sheep $(n=14)$. All the examined animals were females aged between 2-4 years. They were bred and kept on the Sieborowice Farm, Kraków, Poland. Shearing for both species was conducted using a hand clipper or an electric shearing machine, five months prior to examination. Both the Huacaya alpacas and the Merino sheep were kept indoors. Fleece samples were taken for measuring: fibre length, average fibre diameter and thermal insulation. In addition, thermographic examination of both species was performed to estimate the fleece surface temperature. All experimental procedures were approved by the Local Ethical Committee for Experiments on Animals in Wroclaw.

Fleece sampling. Four small fleece samples were taken from each animal at the following sampling sites: left upper trunk (LU), left lower trunk (LL), right upper trunk (RU) and right lower trunk (RL). The fleece was cut about $2 \mathrm{~mm}$ above the base of the skin using scissors. 
Examination of fleece length. The natural length of fibre from Huacaya alpacas and Merino sheep was measured without stretch, using a ruler and a magnifying glass. Fleece length was determined by measuring 10 bundles of fibres per sample with a precision of $0.1 \mathrm{~cm}$.

Examination of fleece diameter. To estimate the diameter of the fibres, 4000 hairs were measured from each animal, 1000 from each sampling site. Fibres were cleaned in lukewarm water with detergent to free them of grease, and were then mounted on slides and immersed in paraffin oil. The measurement of fibre diameter was performed according to Polish Standard PN-72/P04900 using an MP3 lanameter, with magnification of $\times 500$.

Measurement of fleece insulation properties. The measurement of thermal insulation was performed using equipment for the evaluation of insulating materials exposed to thermal radiation produced by Lodz University of Technology (Poland) (Fig. 1).

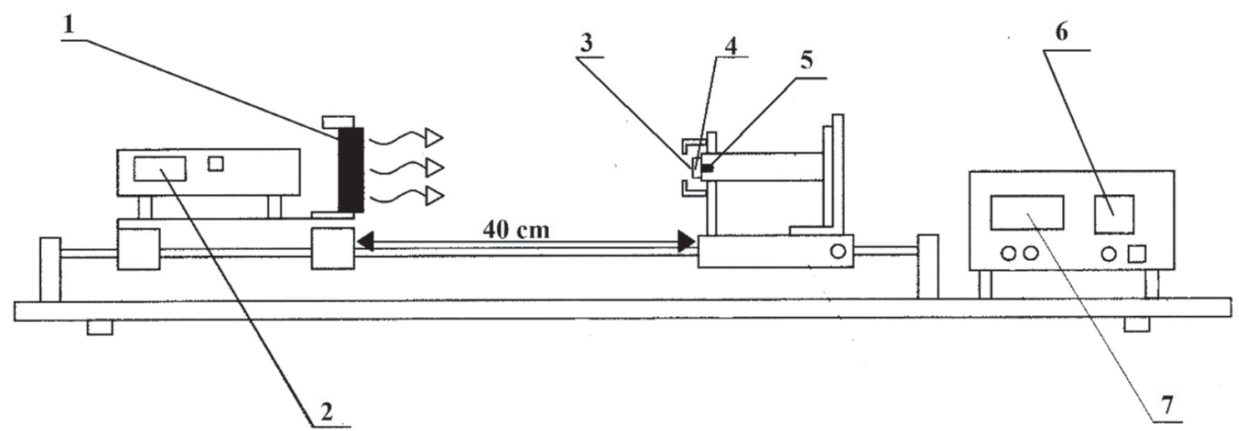

Fig. 1. The scheme of the equipment for the measurement of thermal insulation in materials exposed to thermal radiation produced by Lodz University of Technology (Poland) (1- infrared heater; 2 - infrared heater temperature meter; 3 - measuring sample; 4- aluminium calorimeter; 5temperature indicator; 6- temperature meter; 7- time measurement meter).

To evaluate the heat insulation of Huacaya alpaca and Merino sheep fleeces, a 0.3 g sample from each animal was weighed and placed in a holder so that it covered the aluminium calorimeter without squeezing. The sample was placed $40 \mathrm{~cm}$ away from the heat source at a temperature of $680{ }^{\circ} \mathrm{C}$. The measurement time was 5 minutes for each sample. For each sample, the factor $\mathrm{Rp}\left({ }^{\circ} \mathrm{C} / \mathrm{s}\right)$ was determined, expressing the rate of temperature rise of the calorimeter.

$\mathrm{Rp}=\Delta \mathrm{T} / \Delta \mathrm{t}$

where:

$\mathrm{Rp}$ - rate of temperature rise of the calorimeter with the sample, ${ }^{\circ} \mathrm{C} / \mathrm{s}$

$\Delta \mathrm{T}$ - temperature rise

$\Delta \mathrm{t}$ - heating time

Vet. arhiv 89 (4), 519-528, 2019 
Subsequently the factor qs $\left(\mathrm{kW} / \mathrm{m}^{2}\right)$ was calculated - the density of heat flux penetrating the sample.

$\mathrm{qs}=(\mathrm{m} \times \mathrm{cp} \times \mathrm{R}) / \mathrm{A} \times \alpha$

where:

qs - density of heat flux penetrating the sample, $\left(\mathrm{kW} / \mathrm{m}^{2}\right)$

$\mathrm{m}$ - the mass of aluminium sample of the calorimeter, $0.00716 \mathrm{~kg}$

$\mathrm{cp}$ - specific heat of aluminium, $900 \mathrm{~J} / \mathrm{kg}{ }^{\circ} \mathrm{C}$

A - surface area of the calorimeter, $0.00049 \mathrm{~m}^{2}$

$\alpha$ - absorption coefficient of the blackened surface of the calorimeter, 0.95

Measurements were also made for the empty calorimeter to indicate $\mathrm{R} 0$ (the rate of temperature rise of the calorimeter without the sample) and q0 (the density of heat flux acting on the sample), to calculate the heat transfer rate (HTR). HTR is a measurement of the heat penetrating through a sample subjected to the thermal radiation. It is equal to the ratio of the density of heat flux that has passed through the sample (qs) to the density of heat flux acting on the sample (q0). The lower the HTR, the better the heat insulation. The measurements carried out on the test bench complied with the requirements of Polish Standard PN-EN ISO 6942.

Fleece surface temperature. The thermographic examination was performed indoors using a high resolution VarioCam infrared camera 640×480 (InfraTec, Dresden, Germany) at an ambient temperature of between $5.2-7.6^{\circ} \mathrm{C}$ for Huacaya alpacas and $7.9-9.6^{\circ} \mathrm{C}$ for Merino sheep. The emissivity $(\varepsilon)$ was set to 1 for all readings. The animals were studied at rest before daily turnout for grazing, and moved to a separate box to avoid close contact 10 minutes prior to imaging. Images were recorded while the animals were standing and were held by the head area to maintain the same position. Any straw or mud present in the imaging field of view was removed before the thermographic examination, and wet or torn fleece, or scars, inflamed or swollen areas were recorded for each examined animal. All thermographic images were taken perpendicular to each subject to avoid any possible errors due to angle. Each animal had two thermographic images recorded to include both lateral aspects of the trunk from a distance of $2.5 \mathrm{~m}$ (Figs. 2, 3). Regions of interests (ROIs), with a size of $200 \times 300$ pixels, were determined for each thermographic image of both species. On each image 2 ROIs were defined at the sites where fleece samples were taken later. The temperatures were determined by IRBIS 3 Professional software (InfraTec, Dresden, Germany) using the mean pixel value in the rectangular ROI. Statistical analysis was conducted with STATISTICA 10 software (StatSoft, Inc., Tulsa, Ok., USA). The statistical characteristics of the quantitative variables were presented as arithmetic means (M) and their standard deviations (SD). The normality of the variable distribution was verified by Shapiro-Wilk tests. The Student $t$-test for independent 
variables was used to compare the statistical characteristics of normally-distributed quantitative independent variables. The significance of differences between mean values of variables with nonhomogeneous variances was verified using the Student $t$-test with independent estimation of variance. The homogeneity of variance was examined with the Levene and Brown-Forsyth tests. A P value of $<0.05$ was considered statistically significant.

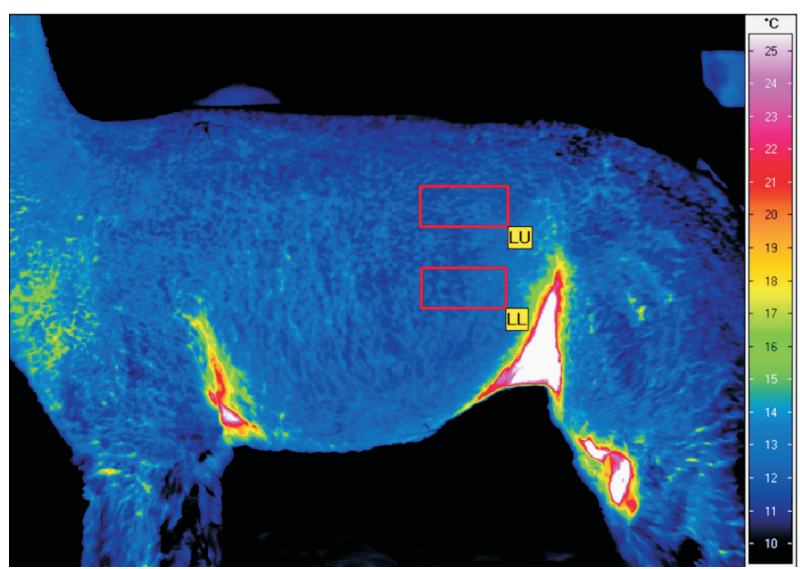

Fig. 2. Thermogram of the left lateral aspect of the Huacaya alpaca's trunk. Measured Regions of Interest (ROI): LU - left upper trunk, LL - left lower trunk.

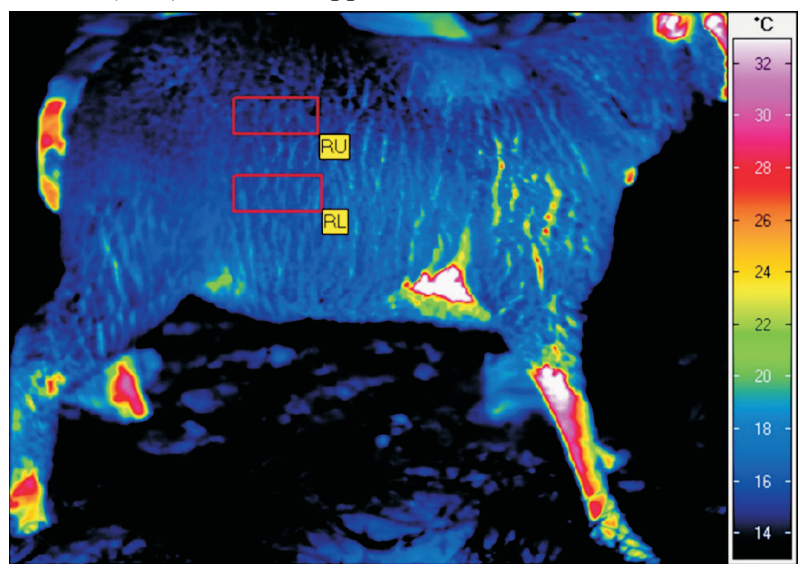

Fig. 3. Thermogram of the right lateral aspect of the Merino sheep's trunk. Measured Region of Interest (ROI): RU - right upper trunk, RL - right lower trunk. 


\section{Results}

The results for Huacaya alpaca and Merino sheep fleece samples are presented in Table 1. In all measuring areas, Merino sheep had significantly $(\mathrm{P}<0.001)$ longer (on average by $23 \%$ ) and thicker (by $17 \%$ ) fibres, but poorer insulation (a higher value of HTR) by as much as $20 \%$. Summary statistics for Huacaya alpaca and Merino sheep fleece surface temperatures are presented in Table 2. The Huacaya alpaca fleece temperature was significantly $(\mathrm{P}<0.001)$ cooler (by 1 to $2^{\circ} \mathrm{C}$ ) compared to Merino sheep at all ROIs.

Table 1. Characteristics of Huacaya and Merino sheep fleece samples, by sampling site (Means $\pm \mathrm{SD})$

\begin{tabular}{|c|c|c|c|c|}
\hline \multirow[b]{2}{*}{ Fleece parameters } & \multicolumn{4}{|c|}{ Sampling sites } \\
\hline & LU & LL & RU & RL \\
\hline \multicolumn{5}{|l|}{ Length (cm) } \\
\hline Huacaya alpacas & $3.18 \pm 0.52$ & $3.24 \pm 0.54$ & $3.25 \pm 0.64$ & $3.29 \pm 0.67$ \\
\hline \multirow[t]{2}{*}{ Merino sheep } & $3.99 \pm 0.40$ & $3.99 \pm 0.40$ & $4.08 \pm 0.45$ & $4.08 \pm 0.45$ \\
\hline & $\mathrm{P}<0.001$ & $\mathrm{P}<0.001$ & $\mathrm{P}<0.001$ & $\mathrm{P}<0.001$ \\
\hline \multicolumn{5}{|l|}{ Diameter $(\mu \mathrm{m})$} \\
\hline Huacaya alpacas & $18.9 \pm 2.8$ & $20.4 \pm 3.7$ & $18.7 \pm 3.1$ & $20.7 \pm 3.1$ \\
\hline \multirow[t]{2}{*}{ Merino sheep } & $23.3 \pm 3.3$ & $23.8 \pm 3.0$ & $23.2 \pm 2.8$ & $24.1 \pm 3.0$ \\
\hline & $\mathrm{P}<0.001$ & $\mathrm{P}=0.007$ & $\mathrm{P}<0.001$ & $\mathrm{P}=0.003$ \\
\hline \multicolumn{5}{|c|}{ Heat insulation, HTR } \\
\hline Huacaya alpacas & $0.67 \pm 0.10$ & $0.71 \pm 0.07$ & $0.67 \pm 0.11$ & $0.72 \pm 0.10$ \\
\hline \multirow[t]{2}{*}{ Merino sheep } & $0.81 \pm 0.08$ & $0.85 \pm 0.04$ & $0.87 \pm 0.06$ & $0.87 \pm 0.06$ \\
\hline & $\mathrm{P}<0.001$ & $\mathrm{P}<0.001$ & $\mathrm{P}<0.001$ & $\mathrm{P}<0.001$ \\
\hline
\end{tabular}

$\mathrm{M}$ - arithmetic mean, SD - standard deviation, P - the level of significance, LU - left upper trunk, LL - left lower trunk, RU - right upper trunk, RL - right lower trunk, HTR - the ratio of the density of heat flux that has passed through the sample (qs) to the density of heat flux acting on the sample (q0). Higher values indicate lower insulation.

Table 2. Coat surface temperatures for alpacas and sheep taken by infrared thermography, averaged for the ROIs (Regions of interest); (Means \pm SD)

\begin{tabular}{|l|c|c|c|c|}
\hline \multirow{2}{*}{$\begin{array}{l}\text { Temperature } \\
\left({ }^{\circ} \mathrm{C}\right)\end{array}$} & \multicolumn{4}{|c|}{ ROI } \\
\cline { 2 - 5 } & LU & LL & RU & RL \\
\hline Huacaya alpacas & $13.2 \pm 1.2$ & $13.9 \pm 1.5$ & $13.3 \pm 1.2$ & $14.0 \pm 1.2$ \\
\hline Merino sheep & $14.8 \pm 0.8$ & $15.6 \pm 1.1$ & $14.9 \pm 0.8$ & $15.6 \pm 0.9$ \\
\hline & $\mathrm{P}<0.001$ & $\mathrm{P}<0.001$ & $\mathrm{P}<0.001$ & $\mathrm{P}<0.001$ \\
\hline
\end{tabular}

LU - left upper trunk, LL - left lower trunk, RU - right upper trunk, RL - right lower trunk 


\section{Discussion}

Animal coats are one of the most efficient insulating materials. The thermal insulation of the coat varies between individual animals due to factors such as differences in coat length, thickness, and the density of the hair (MOORE et al., 2011). GERKEN (1997) found that a minimum fibre length seems to be necessary to benefit from the insulation properties of the fibre. Annual regrowth of fleece ranges from 7.7 to $12.6 \mathrm{~cm}$ for Huacaya alpacas (FRANK et al., 2006) and $8.4 \mathrm{~cm}$ for Merino sheep (SHARMA and PANT, 2013). In our study the fleece had grown for 5 months since shearing, and the fleece length of approximately $3.2 \mathrm{~cm}$ for alpacas and $4 \mathrm{~cm}$ for Merino sheep is consistent with other studies.

CZAPLICKI (2012) reported alpaca fibre diameter in a range from 20.6 to $35.4 \mu \mathrm{m}$ in Poland. In our study the average diameter was $19.7 \mu \mathrm{m}$, which lies outside the range quoted by CZAPLICKI (2012). For comparison, in Australia, the alpaca fibre diameter was reported to range from 17.7 to $46.6 \mu \mathrm{m}$ (McGREGOR and BUTLER, 2004). According to WULIJI et al. (2000) the average thickness of fibres is lower on the alpaca's back than on the side of the trunk. The same results were found in our study, where alpacas had thinner fibres on the upper parts of the trunk compared to the lower.

The average fibre diameter of the Merino sheep was about $23.6 \mu \mathrm{m}$ in our study and was similar to that obtained by REIS and SAHLU (1994), who indicated 20 - $30 \mu \mathrm{m}$, and SHARMA and PANT (2013), who found an average fibre diameter of $23 \mu \mathrm{m}$.

We found that Merino sheep had longer and thicker fleeces, but less efficient thermal insulation compared to Huacaya alpacas. Differences in thermal insulation between the fleeces of two species may be associated with variations in the internal structure of the individual fibres (WANG et al., 2005; MOORE et al. 2011; CZAPLICKI, 2012). Merino sheep fleece consists of one type of fibre without a medulla, whereas only the minority of alpaca fibres are medulla-free. In alpacas medullae may be continuous or fragmented (ANTONINI, 2010; GERKEN 2010; CZAPLICKI, 2012).

According to CENA and CLARK (1973), coat structure has an important influence on the radiative energy balance of an animal. Coat surface temperature will be a function of a temperature profile within the coat, and of the coat structure. In this study we found that Huacaya alpacas had a lower fleece surface temperature compared to Merino sheep. The lower surface temperature indicates that animals conserve their body temperature better than sheep. However, the rectal temperature was not measured.

Our study has a number of limitations. We used a lanameter to measure fibre diameter, which CZAPLICKI (2012) has criticised for its limited accuracy, in comparison to laser and scanning electron microscopy techniques. Our simple method of fleece sampling using scissors may have also introduced a source of error in the fibre length 
measurement. Fleece temperature measurements were taken in slightly different ambient temperature conditions for the two species: this is likely to contribute significantly to the differences in fleece temperature observed, and would need to be better controlled for the development of a complete model of heat transfer in the species. Nonetheless, these initial measurements demonstrate that infrared thermography is a practical and viable technique to collect temperature data for small ruminant research.

\section{Conclusions}

It was found that Huacaya alpacas have greater thermal insulation properties than Merino sheep (by about 20\%). This difference between the species appears to be associated with variations in the individual construction of the fibres rather than differences in the fibre length and diameter. Infrared thermography also provides valuable information about fleece surface temperatures in vivo, which can be used to validate models of heat exchange in homeotherms. Environmental conditions must be controlled rigorously to enable those models to be applied.

\section{References}

ANTONINI, M. (2010): Hair follicle characteristics and fibre production in South American camelids. Animal 4, 1460- 1471.

DOI: $10.1017 / \mathrm{S} 1751731110001035$

CENA, K., J. A. CLARK (1973): Thermal radiation from animal coats: coat structure and measurements of radiative temperature. Phys. Med. Biol. 18, 432-443.

CENA, K. (1974): Radiative heat loss from animals and man. In: Heat Loss from Animals and Men: Assessment and Control. (Monteith J. L., L. E. Mount, Eds.), London, Butterworths, pp. 33-58.

CZAPLICKI, Z. (2012): Properties and structure of polish alpaca wool. Fibres Text. East. Eur. 20, $8-12$.

FRANK, E. N., M. V. H. HICK, C. D. GAUNA, H. E. LAMAS, C. RENIERI, M. ANTONINI (2006): Phenotypic and genetic description of fibre traits in South American domestic camelids (llamas and alpacas). Small Rumin. Res. 61, 113-129.

DOI: 10.1016/j.smallrumres.2005.07.003

GERKEN, M. (1997): Application of infra-red thermography to evaluate the influence of the fibre on body surface temperature in llamas. European Fine Fibre Network, Occasional Publication $6,65-71$.

GERKEN, M. (2010): Relationships between integumental characteristics and thermoregulation in South American camelids. Animal 4, 1451-1459.

DOI: $10.1017 / \mathrm{S} 1751731109991443$ 
McARTHUR, A. J., J. L. MONTEITH (1980): Air movement and heat loss from sheep. II. Thermal insulation of fleece in wind. Proceedings of the Royal Society of London. Series B. Bio. Sci. 1980; 209: 209-217.

DOI: $10.1098 / \mathrm{rspb} .1980 .0091$

McCAFFERTY, D. J. (2007): The value of infrared thermography for research on mammals: previous applications and future directions. Mamm. Rev. 3, 207-223.

DOI: $10.1111 / \mathrm{j} .1365-2907.2007 .00111$

McGREGOR, B. A., K. L. BUTLER (2004): Sources of variation in fibre diameter attributes of Australian alpacas and implications for fleece evaluation and animal selection. Aust. J. Agric. Res. 2004; 55: 433-442.

DOI: $10.1071 / \mathrm{AR} 03073$

MOORE, K. E., D. BLACHE, S. K. MALONEY (2011): Fibre diameter and insulation in alpacas: The biophysical implications. Small. Rumin. Res. 96, 165-172.

DOI: 10.1016/j.smallrumres.2011.01.01

POLISH STANDARD PN-72/P-04900 (1972): Methods of textile raw materials tests, wool (in Polish).

REIS, P., J. T. SAHLU (1994): The nutritional control of the growth and properties of mohair and wool fibers: a comparative review. J. Anim. Sci. 72, 1899-1907.

SCOBIE, D. R., A. J. GROSVENOR, A. R. BRAY, S. K. TANDON, W. J., MEADE, A. M. B. COOPER (2015): A review of wool fibre variation across the body of sheep and the effects on wool processing. Small. Rumin. Res. 133, 43-53.

DOI: 10.1016/j.smallrumres.2015.10.025

SHAKYAWAR, D. B., P. C. PATNI, N. P. GUPTA (2007): Studies on animal fibre blended handmade felts: Part II- Frictional, compressional and thermal properties. J. Fibre Text. Res. 32, 301-305.

SHARMA, A., S. PANT (2013): Studies on camel hair - merino wool blended knitted fabrics. Indian J. Fibre Text. Res. 38, 317-319.

SOROKO, M., E. JODKOWSKA, K. DUDEK (2015): Thermography diagnosis in monitoring the annual training cycle of racehorses. Medycyna Weterynaryjna-Veterinary Medicine-Science and Practice 71, 52-58

SOROKO, M., K. HOWELL, K. DUDEK, R. HENKLEWSKI, P. ZIELIŃSKA (2017): The influence of breed, age, gender, training level and ambient temperature on forelimb and back temperature in racehorses. Anim. Sci. J. 88, 347-355.

DOI: 10.1111 asj.12631

WANG, H., X. LIU, X. WANG (2005): Internal structure and pigment granules in colored alpaca fibers. Fibers and Polymers 6, 263-268.

DOI: $10.1007 / \mathrm{BF} 02875652$ 
WULIJI, T., G. H. DAVIS, K. G. DODDS, P. R. TURNER, R. N. ANDREWS, G. D. BRUCE (2000): Production performance, repeatability and heritability estimates for live weight, fleece weight and fiber characteristics of alpacas in New Zealand. Small Rumin. Res. 37, 189-201.

DOI: $10.1016 /$ S0921-4488(00)00127-9

\section{SOROKO, M., A. WYROSTEK, K. HOWELL, K. DUDEK: Usporedba izolacijskih svojstava vune alpaka (Huacayo alpaca) i merino ovaca. Vet. arhiv 89, 519-528, 2019.}

\section{SAŽETAK}

Cilj ovoga istraživanja jest procjena i usporedba vune alpaka (Huacayo alpaca) i merino ovaca kao toplinskog izolatora. Istraživanje je obuhvatilo 13 klinički zdravih alpaka i 14 merino ovaca. Uzorci vune uzeti su s lateralnog dijela trupa svake životinje kako bi se izmjerili dužina i promjer vlakana. Izolacijska svojstva svakoga uzorka određena su kalorimetrijskom metodom. Također su učinjene infracrvene termografske snimke lateralnog dijela trupa s kojega su uzeti uzorci u obje skupine u zatvorenom prostoru. Na svakoj su snimci određene četiri regije (na temelju mjesta uzorkovanja) te je izračunata prosječna temperatura. Vuna merino ovaca imala je znakovito duža i deblja vlakna od vune alpaka ( $\mathrm{P}<0,001)$, ali manje učinkovitu izolaciju (oko $20 \%$ u svim uzorcima. Ovce u sličnim pokusnim uvjetima imale su znakovito višu temperaturu površine vune $\left(1-2^{\circ} \mathrm{C}\right)$ od alpaka. Infracrvena termografija pruža podatke i o temperaturi površine vlakana in vivo, što se može upotrijebiti za vrednovanje modela u izmjeni temperature toplokrvnih životinja.

Ključne riječi: alpaka; promjer vlakna; dužina vlakna; vuna; ovca; toplinska izolacija; infracrvena termografija 